\title{
ПСИХОЛОГИЧЕСКИЕ И СОЦИАЛЬНЫЕ ФАКТОРЫ РЕСОЦИАЛИЗАЦИИ БЫВШИХ ОСУЖДЕННЫХ К ЖИЗНИ В ЗАКОНОПОСЛУШНОМ ОБЩЕСТВЕ
}

\section{PSYCHOLOGICAL AND SOCIAL FACTORS OF RE-SOCIALIZATION OF FORMER CONVICTS TO LIFE IN A LAW-ABIDING SOCIETY}

\section{E. Raspopin}

Summary: The aim of the work was to study the psychological and social factors of successful re-socialization of former convicts to life in a lawabiding society. The main method of data collection was a survey, the processing of the data obtained was carried out using content analysis. The subjects were convicts who were re-serving their sentences, as well as relatives and friends of the convicts. According to the results of the study, it was found that convicts see primarily external, social resources as factors of successful re-socialization, and pay little attention to changing their life position. Relatives and friends also note that social resources are an essential factor in successful re-socialization. But, at the same time, they pay more attention to the need to change the wrong behavior of the convicts themselves. The results obtained can be used to organize preventive measures aimed at preventing the commission of repeated crimes by persons released from prison.

Keywords: convicts, psychology of convicts, resocialization, criminal behavior, recidivism.

\section{Введение}

$\mathrm{B}$ настоящее время перед пенитенциарной психологией стоит ряд важных практических задач, таких, как разработка методик прогнозирования преступного поведения личности [5], оценка степени исправления осужденных [6], изучение факторов, оказывающих влияние на личность осужденного в период отбывания наказания [9] и т.д.

Также важное практическое значение имеет проблема изучения факторов, оказывающих влияние на процесс ресоциализации бывших осужденных, их адаптации к жизни в законопослушном обществе после освобождения из мест лишения свободы [2, 3]. Ранее нами было проведено исследование, целью которого выступало изучение причин, препятствующих успешной ресоциализации этих людей. В исследовании приняли участие повторно осужденные и их близкие. По результатам исследования было установлено, что все причины можно обобщить в три основные группы. Первая группа - это

\author{
Распопин Евгений Владимирович \\ К.nсх.н., дочент, Уральский юридический институт МВД \\ России (Екатеринбург) \\ ev73@mail.ru
}

Аннотация: Целью работы выступило изучение психологических и социальных факторов успешной ресоциализации бывших осужденных к жизни в законопослушном обществе. Основным методом сбора данных являлся опрос, обработка полученных данных осуществлялась при помощи контент-анализа. В качестве испытуемых выступали осужденные, повторно отбывающие наказание, родные и близкие осужденных. По результатам исследования было установлено, что осужденные в качестве факторов успешной ресоциализации видят, прежде всего, внешние, социальные ресурсы, и мало внимания уделяют изменению своей жизненной позиции. Родные и близкие также отмечают, что социальные ресурсы являются существенным фактором успешной ресоциализации. Но, вместе с тем, они уделяют больше внимания необходимости изменения неправильного поведения самих осужденных. Полученные результаты могут использоваться в целях организации профилактических мероприятий, направленных на предупреждение совершения повторных преступлений лицами, освободившимися из мест лишения свободы.

Ключевые слова: осужденные, психология осужденных, ресоциализация, преступное поведение, рецидивная преступность.

неправильное поведение самого бывшего осужденного. Например, нежелание трудиться, безответственное отношение к своим близким, употребление психоактивных веществ и т.д. Вторая группа - это проблемное поведение окружающих людей. Например, негативное влияние «старой компании», недоверие со стороны окружающих, отсутствие поддержки со стороны близких. Третья группа - неблагоприятные социально-экономические факторы. Например, отсутствие жилья и работы. При этом сами осужденные в качестве основных причин, мешающих им нормально адаптироваться к жизни в законопослушном обществе, чаще называют внешние факторы - негативное влияние окружающих и неблагоприятные социально-экономические условия. Что же касается родных и близких, то они чаще отмечают, что основные причины, по которым осужденные не могут вернуться к нормальной жизни, коренятся в деструктивном поведении самих бывших осужденных [7]. Таким образом, на первый план здесь выступает проблема локуса контроля [1], то есть способности осужденных брать на себя личную ответственность за свое поведение. 
В целом, полученные результаты указывают основные пути, направления для организации психопрофилактической и коррекционной работы с бывшими осужденными для того, чтобы помочь им адаптироваться к жизни в законопослушном обществе. Однако для полноценного решения проблемы необходимо также изучить те факторы, которые не только препятствуют, но и способствуют успешной ресоциализации. Эти факторы представляют собой своего рода точку опоры, положительный полюс, который может быть использован как ресурс для восстановления нарушенной адаптации осужденного.

В связи с этим целью данной работы выступило изучение психологических и социальных факторов успешной ресоциализации бывших осужденных к жизни в законопослушном обществе.

\section{Прочедура и методы проведения исследования}

Выборку исследования составили:

1. осужденные, повторно отбывающие наказание в исправительных учреждениях ФСИН России в количестве 121 человек;

2. близкие и родственники осужденных в количестве 90 человек.

Сбор данных проводился при помощи опроса [10]. Испытуемым предлагалось в свободной форме ответить на вопрос о том, что могло бы помочь бывшему осужденному адаптироваться к жизни на свободе и больше никогда не попадать в места лишения свободы. Ответы испытуемых обрабатывались при помощи контент-анализа [4]. Категории контент-анализа определялись путем предварительного изучения ответов испытуемых и последующего объединения этих ответов вокруг основных смысловых тем, которым они соответствуют. Вначале был проведен контент-анализ ответов в группах осужденных и их близких. После этого проводился сравнительный анализ частоты упоминания тех или иных категорий ответов между группами. Для математической обработки применялся $\varphi^{*}$ критерий Фишера [8].

\section{Результаты исслехования}

По результатам изучения ответов осужденных было установлено, что, по их мнению, успешной ресоциализации могут способствовать следующие факторы:

1. обеспеченность работой, регулярная и достойная оплата труда (в отчетах осужденных данная категория встречается в 34,3\% случаев);

2. доверие и поддержка со стороны семьи и близких $(23,0 \%)$;

3. социальная помощь в виде денежных выплат, решения жилищного вопроса, восстановления документов, консультаций специалистов (юристов, психологов) (12,7\%);

4. избавление от вредных (алкоголь, наркотики) привычек (6,4\%);

5. уход от негативного влияния «старой компании», разрыв связей с преступным миром (5,4 \%);

6. достаточное количество денег (4,9\%);

7. изменение жизненной позиции, переосмысление ценностей, поиск целей в жизни, принятие ответственности за свое будущее (4,4\%);

8. развитие способности к саморегуляции, контроль над своим поведением и поступками (2,9\%);

9. стабильный, упорядоченный образ жизни (2,9\%);

10. изменение отношения со стороны общества, снижение контроля со стороны правоохранительных органов (2,9\%).

По мнению близких, успешной ресоциализации бывших осужденных могут способствовать следующие факторы:

1. работа, регулярная и достойная оплата труда (данная категория упоминается в отчетах родных и близких в 26,0 \% случаев);

2. вера и поддержка со стороны семьи и близких $(19,7 \%)$;

3. изменение жизненной позиции, наличие позитивных жизненных целей, принятие ответственности за свое будущее $(15,7 \%)$;

4. избавление от вредных привычек (12,6\%);

5. делегирование бывшему осужденному ответственности за свою жизнь и за благополучие своих близких, развитие у него чувства долга перед собой и другими людьми (11,8\%);

6. систематический контроль над поведением бывшего осужденного со стороны родных и близких, установление для него правил поведения, которые он должен соблюдать, требовательность и неуклонность в необходимости соблюдении этих правил $(8,7 \%)$;

7. уход от негативного влияния «старой компании», разрыв связей с преступным миром (3,1\%);

8. социальная помощь в виде денежных выплат, решения жилищного вопроса, восстановления документов, консультаций специалистов (2,4\%).

Как видно из полученных результатов, и осужденные, и их близкие неоднократно обращались к одним и тем же темам. В связи с этим, между результатами осужденных и их близких был проведен сравнительный анализ. Значимые различия были получены по следующим категориям:

1. осужденные чаще видят путь к успешной ресоциализации в получении социальной помощи в виде временных выплат, поиска жилья, восстановления документов, помощи специалистов ( $p \leq 0,01)$;

2. близкие чаще отмечают, что пройти процесс ресоциализации могут помочь такие факторы, как 
изменение жизненной позиции, принятие ответственности за свое будущее ( $p \leq 0,01)$ и избавление от вредных привычек ( $\leq \leq 0,05)$.

Таким образом, осужденные видят в качестве факторов успешной ресоциализации, прежде всего, внешние, социальные ресурсы, и меньше внимания уделяют изменению своей жизненной позиции. Родные и близкие больше внимания уделяют необходимости изменения поведения самих бывших осужденных. Но также они отмечают, что существенным фактором успешной ресоциализации являются и социальные ресурсы, такие, как трудоустройство, поддержка семьи и т.д. При этом близкие, с одной стороны, говорят о том, что бывшие осужденные должны сами принимать на себя ответственность за свое поведение и, вместе с тем, отмечают, что они нуждаются в постоянном внешнем контроле.

\section{Выводы}

1. В целом можно выделить две основные группы факторов, способствующих ресоциализации осужденных - внешние и внутренние. Внешние факторы - это помощь со стороны социального окружения. Внутренние - актуализация ресурсов личности самого осужденного, необходимых для решения стоящих перед ним проблем.

2. Осужденные на первый план ставят внешние, социальные факторы. Их родные и близкие, не отрицая положительного значения внешних факторов, подчеркивают необходимость актуализации внутренних ресурсов личности самих осужденных.

3. Среди конкретных факторов, способствующих процессу ресоциализации, на первый план выступают:

а) по мнению осужденных: работа, хорошая оплата труда; доверие и поддержка со стороны семьи и близких; социальная помощь и др.;

б) по мнению родных и близких: работа, достойная оплата труда; доверие и поддержка со стороны семьи и близких; изменение жизненной позиции, принятие бывшим осужденным ответственности за свое будущее; избавление от вредных привычек; делегирование бывшему осужденному ответственности за свое поведение и, в то же время, постоянный контроль над его поведением со стороны близких и др.

4. Эти факторы представляют собой ресурс, который может быть использован для восстановления нарушенной адаптации осужденного.

\section{ЛИТЕРАТУРА}

1. Бажин Е.Ф., Голынкина Е.А., Эткинд А.М. Опросник уровня субъективного контроля (УСК). - М.: Смысл, 1993. - 16 с.

2. Васильев В.Л. Юридическая психология. - СПб.: Питер, 2009. - 608 с.

3. Дмитриев Ю.А., Казак Б.Б. Пенитенциарная психология. - Ростов-на-Дону: Феникс, 2007. - 681 с.

4. Дружинин В.Н. Экспериментальная психология. - СПб.: Питер, 2000. - 320 с.

5. Логинов Е.А. Возможности криминологического прогнозирования индивидуального преступного поведения // Психопедагогика в правоохранительных органах. - 2013. - № 4 (55). - С. 77-82.

6. Пастушеня А.Н. Психологическая диагностика степени исправления осужденных: основы теории и методики // Прикладная юридическая психология. 2015. - № 4. - C 10-20.

7. Распопин Е.В. Изучение причин, препятствующих успешной ресоциализации лиц, освободившихся из мест лишения свободы // Современная наука: актуальные проблемы теории и практики. Серия: Познание. - 2020. - № 07. - С. 90-94.

8. Сидоренко Е.В. Методы математической обработки в психологии. - СПб.: Речь, 2007. - 350 с.

9. Скрипка Л.В. Эмоциональные состояния впервые осужденных в процессе отбывания наказания // Прикладная юридическая психология. - 2014. № 3. - С $98-102$.

10. Худяков А.И. Экспериментальная психология в схемах и комментариях. - СПб.: Питер, 2008. - 320 с. 